\title{
AKUNTABILITAS PENGELOLAAN ALOKASI DANA DESA DI DESA PUNAGAYA KECAMATAN BANGKALA KABUPATEN JENEPONTO
}

\author{
Muslimin $^{1}$, Mappamiring ${ }^{2}$, St. Nurmaeta ${ }^{1}$ \\ ${ }^{1}$ Program Studi Ilmu Pemerintahan Fakultas Ilmu Sosial dan Ilmu Politik \\ Universitas Muhammadiyah Makassar \\ Jl. Sultan Alauddin No. 259 Makassar 90221 \\ Telp. 0411-866972 ext.107.Fax.0411-8655888 \\ muslimin12@yahoo.co.id nurmaeta@gmail.com \\ ${ }^{2}$ Program Studi Ilmu Administrasi Negara Fakultas Ilmu Sosial dan Ilmu Politik \\ Universitas Muhammadiyah Makassar \\ Jl. Sultan Alauddin No. 259 Makassar 90221 \\ Telp. 0411-866972 ext.107.Fax.0411-8655888 \\ mappamiring@yahoo.com
}

\begin{abstract}
The purpose of this study is to describe and explain the accountability of the management of village fund allocation In the Punagaya Village, District of Bangkala Regency of Jeneponto. This type of research is quantitative descriptive and sample as many as 40 employees and communities by using a sampling technique that uses totality probability of members of the population. Data collected by using such instruments; Observations, questionnaires and documentation of the respondents. The data were analyzed statistically using the quantitative simple frequency table. Results showed that accountability for the management of the village fund allocation in the village of Punagaya, District of Bangkala, Regency of Jeneponto. Limiting factor accountability village fund allocation skills, desires and level of participation. Planning program ADD (Village Fund Allocation) in the village of Punagaya gradually been implementing the concept of participatory development of rural communities.
\end{abstract}

Keywords: accountability, village fund allocation

\begin{abstract}
ABSTRAK
Tujuan penelitian ini adalah menggambarkan dan menjelaskan akuntabilitas pengelolaan alokasi dana desa Di Desa Punagaya Kecamatan Bangkala Kabupaten Jeneponto. Jenis penelitian adalah kuantitatif dan sampelnya sebanyak 40 orang pegawai dan masyarakat dengan menggunakan teknik probability sampling yang menggunakan kesuluruhan dari anggota populasi. Data dikumpul dengan menggunakan instrument berupa; Observasi, Kuesioner Dan Dokumentasi terhadap responden. Data tersebut dianalis secara statistic deksriptif kuantitatif dengan menggunakan tabel frekuensi secara sederhana. Hasil penelitian menunjukkan adanya akuntablitas pengelolaan alokasi dana desa di Desa Punagaya Di Kecamatan Bangkala Kabupaten Jeneponto. Faktor akuntabilitas alokasi dana desa terbatas pada keterampilan, keinginan dan tingkat partisipasi. Perencanaan program ADD (Alokasi Dana Desa) di Desa Punagaya secara bertahap telah melaksanakan konsep pembangunan partisipatif masyarakat desa.
\end{abstract}

Kata kunci : Akuntabilitas, alokasi dana desa 


\section{A. PENDAHULUAN}

Seiring dengan ditetapkannya Undang-Undang Nomor 32 Tahun 2004 tentang Pemerintahan Daerah maka Penyelenggaraan pemerintahan di daerah khususnya kabupaten/kota dilaksanakan menurut asas otonomi dan tugas pembantuan dengan prinsip otonomi seluas-luasnya dalam sistem dan prinsip Negara Kesatuan Republik Indonesia. Penyelenggaraan pemerintahan daerah yang demikian kemudian lebih akrab disebut Otonomi Daerah. Dalam perkembangan otonomi daerah, pemerintah pusat semakin memperhatikan dan menekankan pembangunan masyarakat desa melalui otonomi pemerintahan desa. Penyelenggaraan pemerintahan dan pembangunan desa harus mampu mengakomodasi aspirasi masyarakat, mewujudkan peran aktif masyarakat untuk turut serta bertanggungjawab terhadap perkembangan kehidupan bersama sebagai sesama warga desa.

Konsep tentang Akuntabilitas secara harfiah dalam bahasa inggris biasa disebut dengan accoutability yang diartikan sebagai "yang dapat dipertanggungjawabkan" dalam kata sifat disebut sebagai accountable. Lalu apa bedanya dengan responsibility yangjuga diartikan sebagai "tanggung jawab". Pengertian accountability dan responsibility seringkali diartikan sama. Padahal maknanya jelas sangat berbeda. Beberapa ahli menjelaskan bahwa dalam kaitannya dengan birokrasi, responsibility merupakan otoritas yang diberikan atasan untuk melaksanakan suatu kebijakan. Sedangkan accountability merupakan kewajiban untuk menjelaskan bagaimana realisasi otoritas yang diperolehnya tersebut.

Akuntabilitas publik merupakan elemen terpenting dan merupakan tantangan utama yang dihadapi pemerintah dan pegawai negeri. Akuntabilitas berada dalam ilmu sosial yang menyangkut berbagai cabang ilmu sosial lainnya, seperti ekonomi, adminitrasi, politik, perilaku, dan budaya. Selain itu, akuntabilitas juga sangat terkait dengan sikap dan semangat pertanggungjawaban seseorang.

Akuntabilitas secara filosofi timbul karena adanya kekuasaan yang berupa mandat/amanah yang diberikan kepada seseorang atau pihak tertentu untuk menjalankan tugasnya dalam rangka mencapai suatu tujuan tertentu dengan menggunakan sarana pendukung yang ada.

Desa sebagai suatu kesatuan masyarakat hukum yang mempunyai kewenangan mengatur dan mengurus kepentingan masyarakatnya sendiri, dalam melaksanakan tugasnya memerlukan dana yang memadai. Adanya kebutuhan akan dukungan dana maka perlu diatur mengenai sumber pendapatan desa. Dalam Peraturan Pemerintah Nomor 72 Tahun 2005 tentang Desa, dinyatakan bahwa salah satu sumber pendapatan desa adalah bagian dari dana perimbangan keuangan pusat dan daerah yang diterima oleh Kabupaten/Kota untuk Desa paling sedikit $10 \%$ (sepuluh per seratus), yang pembagiannya untuk setiap Desa secara proporsional yang merupakan alokasi dana desa.

Peraturan Daerah Kabupaten Jeneponto Nomor 7 Tahun 2006 sebagaimana telah diubah dengan Peraturan Daerah Kabupaten Jeneponto Nomor 2 Tahun 2009 tentang Sumber Pendapatan Desa, menyebutkan bahwa, Alokasi Dana Desa (ADD) adalah dana yang dialokasikan oleh Pemerintah Kabupaten untuk desa, yang bersumber dari bagian dana perimbangan keuangan pusat dan daerah yang diterima oleh Kabupaten setelah dikurangi belanja pegawai. ADD dimaksudkan untuk membiayai program pemerintahan desa dalam melaksanakan kegiatan pemerintahan dan pemberdayaan masyarakat desa.

Selanjutnya dalam Peraturan Bupati Jeneponto Nomor 29 Tahun 2006 tentang Pedoman Umum Alokasi Dana Desa (ADD) Kabupaten Jeneponto sebagaimana diubah beberapa kali terakhir dengan Peraturan Bupati Jeneponto Nomor 31 Tahun 2009. 
Berdasarkan evaluasi dan penilaian dari Bagian Pemerintahan Desa Setda Kabupaten Jeneponto, Desa Punagaya Kecamatan Bangkala adalah salah satu desa, yang dinilai baik dalam pelaksanaan program Alokasi Dana Desa. Penilaian didasarkan pada beberapa indikator yaitu : (1) meningkatnya akuntabilitas pengelolaan Alokasi Dana Desa dari pengelola Alokasi Dana Desa di tingkat desa, (2) kesesuaian antara rencana dan realisasi baik fisik maupun administrasi dalam penggunaan Alokasi Dana Desa, (3) tertib administrasi dalam pengelolaan dana Alokasi Dana Desa, dan (4) meningkatnya pengetahuan masyarakat tentang Alokasi Dana Desa.

Dalam pelaksanaan program Alokasi Dana Desa, belum semua desa dapat berjalan seperti yang diharapkan. Pemerintah Desa masih berperan besar dalam pelaksanaan program, sedangkan masyarakat belum terlibat secara optimal.Kondisi ini juga terjadi di Desa Punagaya Kecamatan Bangkala Kabupaten Jeneponto, seperti diungkapkan oleh Sekretaris Desa setempat. Atas dasar hal tersebut penulis tertarik untuk mengetahui bagaimana penerapan governance dalam pelaksanaan program Alokasi Dana Desa di Desa Punagaya Kecamatan Bangkala Kabupaten Jeneponto.

Dari pernyataan di atas menjadi alasan bagi penulis mengambil judul "Akuntabilitas Pengelolaan Alokasi Dana Desa Di Desa Punagaya Kecamatan Bangkala Kabupaten Jeneponto"

\section{B. TINJAUAN PUSTAKA}

Menurut Lembaga Administrasi Negara dan Badan Pengawasan Keuangan dan Pembangunan RI (2000:12), akuntabilitas adalah kewajiban untuk memberikan pertanggungjawaban atau menjawab dan menerangkan kinerja dan tindakan seseorang/pimpinan suatu unit organisasi kepada pihak yang memiliki hak atau yang berwenang meminta pertanggungjawaban. Akuntabilitas adalah hal yang penting untuk menjamin nilai-nilai seperti efisiensi, efektifitas, reliabilitas dan prediktibilitas. Suatu akuntabilitas tidak abstrak tapi kongkrit dan harus ditentukan oleh hukum melalui seperangkat prosedur yang sangat spesifik mengenai masalah apa saja yang harus dipertanggungjawabkan.

$$
\text { Sulistiyani (2004) menyatakan }
$$

bahwa transparansi dan akuntabilitas adalah dua kata kunci dalam penyelenggaraan pemerintahan maupun penyelenggaraan perusahaan yang baik, dinyatakan juga bahwa dalam akuntabilitas terkandung kewajiban untuk menyajikan dan melaporkan segala kegiatan terutama dalam bidang administrasi keuangan kepada pihak yang lebih tinggi. Akuntabilitas dapat dilaksanakan dengan memberikan akses kepada semua pihak yang berkepentingan, bertanya atau menggugat pertanggungjawaban para pengambil keputusan dan pelaksana baik ditingkat program, daerah dan masyarakat. Dalam hal ini maka semua kegiatan yang berkaitan dengan pengelolaan Alokasi Dana Desa harus dapat diakses oleh semua unsur yang berkepentingan terutama masyarakat di wilayahnya.

Selanjutnya Haryanto (2007:10) mengemukaan prinsip-prinsip Good Governance adalah Adanya partisipasi masyarakat, yaitu bahwa semua warga masyarakat mempunyai suara dalam pengambilan keputusan baik secara langsung maupun lembaga-lembaga perwakilan sah yang mewakili kepentingan mereka, Tegaknya supremasi hukum yaitu bahwa kerangka hukum harus adil dan diberlakukan tanpa pandang bulu, Tumbuhnya transparansi yang dibangun atas dasar arus informasi yang bebas dan informasi perlu dapat diakses oleh pihakpihak yang berkepentingan dan memadai dan Peduli pada stakeholder, bahwa lembaga-lembaga dan seluruh proses pemerintahan hatus berusaha melayani semua pihak yang berkepentingan; berorientasi pada konsensus, yang artinya bahwa pemerintah menjembatani kepentingan-kepentingan yang berbeda demi terbangunnya suatu konsensus menyeluruh dalam hal apa yang terbaik bagi kelompok masyarakat. 
Dalam definisi tradisional, Akuntabilitas adalah istilah umum untuk menjelaskan betapa sejumlah organisasi telah memperlihatkan bahwa mereka sudah memenuhi misi mereka Benvenist (1991). Definisi lain menyebutkan akuntabilitas dapat diartikan sebagai kewajibankewajiban dari individu-individu atau penguasa yang dipercayakan untuk mengelola sumber-sumber daya publik danyang bersangkutan dengannya untuk dapat menjawab hal-hal yang menyangkut pertanggungjawabannya. Akuntabilitas terkait erat dengan instrumen untuk kegiatan kontrol terutama dalam hal pencapaian hasil pada pelayanan publik dan menyampaikannya secara transparan kepada masyarakat Arifiyadi (2008).

Menurut Agus Dwiyanto, dkk (2008:57) akuntabilitas adalah suatu ukuran yang menunjukkan seberapa besar tingkat kesusaian penyelenggaraan pelayanan dengan ukuran nilai-nilai atau norma eksternal yang ada di masyarakat atau dimiliki oleh para stakeholders. Nilai dan norma yang berkembang dalam masyarakat tersebut, diantaranya transparansi pelayanan, prinsip keadilan, jaminan penegakan hukum, hak asasi manusia, dan orientasi pelayanan yang dikembangkan terhadap masyarakat.

Menurut Behn (2001:4), akuntabilitas adalah derajat sejauh mana pemerintah menjelaskan (to explain), menjawab (to answer), menjastifikasi (to justify) tindakantindakan spesifik atau apa yang telah mereka kerjakan atau gagal mereka kerjakan (termasuk kesedian menerima konsekuensinya) baik atau jelek. Akuntabilitas menentukan alasan, motif dan pentingnya membuat keputusan serta tindakan di mata manajer publik dan warga.

Dengan demikian, pejabat-pejabat publik tidak hanya akuntabel kepada institusi-institusi melalui mekanisme administratif, politik, dan hukum tetapi juga kepada publik dalam berbagai cara seperti halnya konsultasi, dengar pendapat, dan meminta keterangan publik, organisasi konsumen, kompensasi, pers, kelompok social dan kepentingan, dan sebagainya. Zerei (2000:4).
Alokasi Dana Desa atau ADD adalah bagian keuangan Desa yang diperoleh dari Bagi Hasil Pajak Daerah dan Bagian dari Dana Perimbangan Keuangan Pusat dan Daerah yang diterima oleh kabupaten. Menurut Peraturan Menteri Dalam Negeri Nomor 37 Tahun 2007 tentang Pedoman Pengelolaan Keuangan Desa pada Pasal 18 bahwa Alokasi Dana Desa berasal dari APBD Kabupaten/Kota yang bersumber dari bagian Dana Perimbangan Keuangan Pusat dan Daerah yang diterima oleh Kabupaten/Kota untuk Desa paling sedikit $10 \%$.

Menurut Peraturan Daerah Kabupaten Jeneponto Nomor 10 Tahun 2007 tentang Anggaran Pendapatan dan Belanja Desa bahwa Anggaran Pendapatan dan Belanja Desa selanjutnya disingkat APBDES adalah Rencana Keuangan Tahunan Desa yang dibahas dan disetujui bersama oleh Pemerintah Desa dan Badan Permusyawaratan Desa yang ditetapkan dengan Peraturan Desa dan Dana Alokasi Desa terdapat pada Bantuan Keuangan Pemerintah Kabupaten sebagaimana dimaksud ayat (5) pasal 10 Peraturan Daerah ini meliputi Tunjangan Penghasilan Aparatur Pemerintah Desa (TPAPD), Alokasi Dana Desa (ADD), Penyisihan Pajak dan Retribusi Daerah dan Sumbangan Bantuan lainnya dari Kabupaten.

Alokasi Dana Desa atau ADD adalah bagian keuangan Desa yang diperoleh dari Bagi Hasil Pajak Daerah dan Bagian dari Dana Perimbangan Keuangan Pusat dan Daerah yang diterima oleh kabupaten. Menurut Peraturan Menteri Dalam Negeri Nomor 37 Tahun 2007 tentang Pedoman Pengelolaan Keuangan Desa pada Pasal 18 bahwa Alokasi Dana Desa berasal dari APBD Kabupaten/Kota yang bersumber dari bagian Dana Perimbangan Keuangan Pusat dan Daerah yang diterima oleh Kabupaten/Kota untuk Desa paling sedikit $10 \%$.

Menurut Peraturan Daerah Kabupaten Jeneponto Nomor 10 Tahun 2007 tentang Anggaran Pendapatan dan Belanja Desa bahwa Anggaran Pendapatan dan Belanja Desa selanjutnya disingkat 
APBDES adalah Rencana Keuangan Tahunan Desa yang dibahas dan disetujui bersama oleh Pemerintah Desa dan Badan Permusyawaratan Desa yang ditetapkan dengan Peraturan Desa dan Dana Alokasi Desa terdapat pada Bantuan Keuangan Pemerintah Kabupaten sebagaimana dimaksud ayat (5) pasal 10 Peraturan Daerah.

Tujuan Alokasi Dana Desa dalam pasaL 19 Permendagri Nomor 37 Tahun 2007 adalah Menanggulangi kemiskinan dan mengurangi kesenjangan, meningkatkan perencanaan dan penganggaran pembangunan di tingkat desa dan pemberdayaan masyarakat, meningkatkan pembangunan infrastruktur perdesaan, meningkatkan pengamalan nilainilai keagamaan, sosial budaya dalam rangka mewujudkan peningkatan social, meningkatkan ketrentaman dan ketertiban masyarakat, Meningkatkan pelayanan padamasyarakat desa dalam rangka pengembangan kegiatan sosial dan ekonomi masyarakat, Mendorong peningkatan keswadayaan dan gotong royong masyarakat, Meningkatkan pendapatan desa dan masyarakat desa melalui Badan Usaha Milik Desa (BUMDesa).

\section{Pengelolaan Keuangan Alokasi} Dana Desa (ADD) merupakan bagian yang tidak terpisahkan dari Pengelolaan Keuangan Desa dalam APB Desa oleh karena itu dalam Pengelolaan Keuangan Alokasi Dana Desa (ADD) harus memenuhi Prinsip Pengelolaan Alokasi Dana Desa yaitu Seluruh kegiatan yang didanai oleh Alokasi Dana Desa (ADD) direncanakan, dilaksanakan dan dievaluasi secara terbuka dengan prinsip dari, oleh dan untuk masyarakat, Seluruh kegiatan harus dapat dipertanggungjawabkan secara administratif, teknis dan hukum, Alokasi Dana Desa (ADD) dilaksanakan dengan menggunakan prinsip hemat, terarah dan terkendali., Jenis kegiatan yang akan dibiayai melalui Alokasi Dana Desa (ADD), sengat terbuka untuk meningkatkan sarana Pelayanan Masyarakat berupa Pemenuhan Kebutuhan Dasar, Penguatan Kelembagaan Desa dan kegiatan lainnya yang dibutuhkan
Masyarakat Desa yang diputuskan melalui Musyawarah Desa dan Alokasi Dana Desa (ADD) harus dicatat dalam Anggaran Pendapatan dan Belanja Desa (APBDesa) dan proses penganggarannya mengikuti mekanisme yang berlaku.

\section{METODE PENELITIAN}

Penelitian ini akan dilakukan di Desa Punagaya Kecamatan Bangkala Kabupaten Jeneponto. Waktu penelitian mulai dari bulan Nopember sampai Desember 2013. Jenis penelitian ini adalah deskriptif Kuantitatif terhadap variabel akuntabilitas pengelolaan Alokasi Dana Desa. Penelitian ini tidak menguji hipotesahipotesa, melainkan menjelaskan dan menganalisa secara mendalam tentang fenomena yang diteliti. Populasi dalam penelitian ini adalah seluruh pegawai kantor dan masyarakat desa yang berjumlah 40 orang. Sampelnya adalah sampel non probality dengan tekhnik sampling jenuh artinya keseluruhan pegawai dan masyarakat yang ikut berpartisipasi dijadikan sebagai sampel penelitian sebanyak 40. Menurut Arikomto karena sampel kurang dari 100 orang, maka digunakan teknik tersebut.

Jenis data yang digunakan dalam penelitian ini adalah data Kualitatif merupakan data yang diperoleh dari kantor dan masyarakat dalam bentuk lisan maupun tulisan yang relevan dengan pembahasan masalah inidan data kuantitatif merupakan data yang diperoleh dari kantor Desa Punagaya Kecamatan Bangkala dalam bentuk angka-angka yang berkaitan dengan pembahasan masalah ini sumber data yaitu data primer dan dan sekunder.

Teknik pengumpulan data dalam penelitian ini yaitu Observasi merupakan teknik pengumpulan data, dimana peneliti melakukan pengamatan secara langsung ke objek penelitian untuk melihat dari dekat kegiatan yang dilakukan, Angket (kuesioner) adalah sejumlah pertanyaan tertulis yang digunakan untuk memperoleh informasi dari responden dalam arti laporan tentang pribadinya, atau hal-hal yang ia ketahui 
tentang akuntabilitas pengelolan alokasi dana desa di desa punagaya kecamatan bangkala kabupaten jeneponto dan Dokumentasi adalah digunakan untuk memperoleh sejumlah data melalui bahan dokumen tertulis hal-hal yang relevan dengan kebutuhan penulis.

\section{E. HASIL DAN PEMBAHASAN}

Transparansi adalah keterbukaan prosedur/tata cara, persyaratan, pejabat yang bertanggungjawab, waktu penyelesaian dan rincian biaya ditranformasikan secara terbuka agar mudah diketahui oleh masyrakat baik diminta maupun tidak diminta.

Hasil penelitian memperlihatkan bahwa dari 40 orang responden, 2 orang atau $5 \%$ responden menjawab sangat transparan 18 orang atau $45 \%$ responden menjawab sudah transparan, dan 12 orang atau 30\% responden menjawab cukup transparan, sedangkan 8 orang atau 25\% responden lainnya menjawab masih kurang transparan.

\section{Keadilan}

Keadilan adalah pelaksanaan pelayanan dengan tidak membedakan golongan atau status masyarakat yang akan dilayani. Hasil penelitian memperlihatkan bahwa dari 40 orang responden, 1 orang atau $2.5 \%$ responden menjawab sangat adil 15 orang atau $37.5 \%$ responden menjawab sudah adil, dan 19 orang atau 50\% responden menjawab cukup adil, sedangkan 5 orang atau $12.5 \%$ responden masih kurang adil.

\section{Kesesuaian}

Kesusaian adalah kejelasan dan kepastiaan prosedur/tata cara, persyaratan, pejabat yang bertanggungjawab, waktu penyelesaian dan rincian biaya. Hasil penelitian memperlihatkan bahwa dari 40 orang responden, 2 orang atau 5\% responden menjawab sangat sesuai, 20 orang atau 50\% responden menjawab sudah sesuai, dan 15 orang atau $42.5 \%$ responden menjawab cukup sesuai, sedangkan 3 orang atau $7.5 \%$ responden lainnya menjawab masih kurang sesuai.

\section{Faktor Kendala Dalam Pengelolaan Alokasi Dana Desa}

Keterampilan dan kemanpuan aparatur sangat dipengaruhi oleh latar belakang pendidikan dan pelatihan yang yang pernah diikuti oleh pegawai desa tersebut. Hasil penelitian memperlihatkan bahwa dari 40 orang responden, 3 orang atau $7.5 \%$ responden menjawab sangat baik, 10 orang atau $25 \%$ responden menjawab peningkatan keterampilan dan kemanpuan sudah baik, dan 23 orang atau $55 \%$ responden menjawab peningkatan keterampilan dan kemanpuan cukup baik, sedangkan 5 orang atau $12.5 \%$ responden lainnya menjawab keterampilan dan kemanpuan masih kurang. Keinginan Masyarakat untuk teribat dalam kelembagaan, keinginan masyarakat adalah keinginan untuk mengeluarkan tingkat upaya yang tinggi untuk tujuan organisasi. Pendapat pegawai desa tentang keinginan masyarakat untuk terlibat dalam kelembagaan hasil penelitian memperlihatkan bahwa dari 40 responden, 2 orang atau $2.5 \%$ menjawab sangat baik,15 orang atau $37.5 \%$ responden menjawab peningkatan keinginan masyarakat di Desa punagaya sudah baik, 18 orang atau 45\% responden lainnya menjawab peningkatan keinginan masyarakat di Desa punagaya cukup baik dan 5 orang atau $12.5 \%$ responden lainnya menjawab peningkatan keinginan masyarakat di Desa punagaya masih kurang.

\section{Tingkat Partisipasi Masyarakat}

Partisipasi masyarakat adalah keikutsertaan masyarakat dalam proses pengidentifikasian masalah dan potensi yang ada di masyarakat, pemilihan dan pengambilan keputusan tentang alternatif solusi untuk menangani masalah, pelaksanaan upaya mengatasi masalah, dan keterlibatan masyarakat dalam proses mengevaluasi perubahan yang terjadi.

Untuk mengetahui pendapat pegawai tentang upaya aparatur dalam meningkatkan pasrtisipasi masyarakat dari hasil penelitian memperlihatkan bahwa dari 40 responden, 4 orang atau $10 \%$ 
responden menjawab sangat baik, 20 orang atau $60 \%$ responden menjawab menciptakan tingkat partisipasi di Desa punagaya sudah baik, 17 orang atau 25\% responden menjawab menciptakan tingkat partisipasi di Desa punagaya cukup baik, dan 3 orang atau $15 \%$ responden lainnya hanya menjawab menciptakan tingkat partisipasi di Desa Punagaya masih kurang baik.

\section{PENUTUP}

Berdasarkan hasil penelitian diatas maka penulis mengambil kesimpulan bahwa Perencanaan program ADD (Alokasi Dana Desa) di Desa Punagaya secara bertahap telah melaksanakan konsep pembangunan partisipatif masyarakat desa yang dibuktikan dengan penerapan prinsip partisipatif, responsif, transparansi. guna pembelajaran sumber daya masyarakat desa dalam rangka mewujudkan pemberdayaan masyarakat desa melalui forum Musrenbangdes (Musyawarah Perencanaan Pembangunan Desa), Pelaksanaan program ADD (Alokasi Dana Desa) di Desa Punagaya telah menerapkan prinsip-prinsip partisipatif, responsif, transparan.

Walaupun penerapan prinsip akuntabilitas pada tahap ini masih sebatas pertanggungjawaban fisik, sedangkan sisi administrasi masih belum sepenuhnya dilakukan dengan sempurna, Pertanggungjawaban ADD baik secara teknis maupun administrasi sudah baik, namun dalam hal pertanggungjawaban administrasi keuangan kompetensi sumber daya manusia pengelola merupakan kendala utama, sehingga masih memerlukan pendampingan dari aparat Pemerintah Daerah guna penyesuaian perubahan aturan setiap tahundan Program Alokasi Dana Desa merupakan konsep ideal Pemerintah Kabupaten Jeneponto dalam rangka melaksanakan Pembangunan partisipatif masyarakat desa, ternyata mendapat respon/tanggapan positif masyarakat yang sangat diharapkan keberlanjutannya guna peningkatan pembangunan pedesaan.

\section{DAFTAR PUSTAKA}

Dendhardt, R.B. and Denhardt, J.V. 1998. Public Administration. Action, New York: Wadswort Publishing.

Dwiyanto, Agus ; dkk. 2002. Reformasi Birokrasi Publik di Indonesia. Yogyakarta : Pusat Studi Kependudukan Dan Kebijakan Universitas Gajah Mada.

Gormly Jr, William T dan Bella, Steven J. 2004. "Bureaucracy And Democracy: Accountability And Performance."Washington, DC:CQ Press.

Hasan, Igbal, 2004. Poko-Pokok Statistik Deskriptif. Jakarta, Bumi Aksara.

Haryanto, Sahmuddin, dan Arifuddin, 2007. Akuntansi Sektor Publik. Edisi Pertama: Universitas Diponegoro. Semarang.

Kumorotomo, Wahyudi. 2005. Akuntabilitas Birokrasi Publik: Sketsa Pada Masa Transisi. Yogyakarta: Pustaka Pelajar

Lembaga Administrasi Negara dan Badan Pengawasan Keuangan dan Pembangunan RI 2000, Akuntabilitas dan Good Governance, Modul 1-5, Modul Sosialisasi Sistem Akuntabilitas Kinerja Instansi Pemerintah (AKIP), LAN BPKP RI, Jakarta.

Nurhaeni, Ismi Dwi Astuti. 2011. Reformasi Administrasi Publik Adil Gender. Surakarta. Pidato Pengukuhan Guru Besar Administrasi Publik.

Salamm, Alfitra dan Firman, Noor. 2002. Akuntabilitas Dalam Otonomi Daerah. Jakarta: Pusat Penelitian Politik-LIPI

Sulistiyani, Ambar Teguh, 2004, Kemitraan dan Model-Model Pemberdayaan, gava media, Yogyakarta. 